\title{
Peningkatan Kompetensi Guru Dalam Menyusun Administrasi Pembelajaran Melalui Supervisi Akademik di SDN Jati Baru Tahun Pelajaran 2018/2019
}

\author{
Abdul Malik \\ SDN Jati Baru Kota Bima \\ Email:abdul_malik67@gmail.com
}

\begin{abstract}
Rendahnya kualitas sumber daya manusia ini disebabkan oleh mutu pendidikan di Indonesia yang masih rendah. Pendidikan merupakan suatu kegiatan interaksi antara peserta didik dengan para pendidik serta berbagai sumber pendidikan yang berlangsung dalam situasi pendidikan, pengajaran, latihan serta bimbingan. Agar pencapaian hasil pembelajaran maksimal, maka dibutuhkan sosok guru yang professional. Penelitian ini bertujuan Untuk mengetahui Peningkatan Kompetensi Guru Dalam Menyusun Administrasi Pembelajaran Melalui Supervisi Akademik di SDN Jati Baru Tahun Pelajaran 2018/2019. Jenis ini adalah Penelitian Tindakan Sekolah (PTS), yang dirancang dalam dua siklus, tiap siklus terdiri dari empat tahapan, yaitu: perencanaan, pelaksanaan, pengamatan, dan refleksi. Subyek dalam penelitian ini adalah guru SDN Jati Baru sebanyak 12 orang. Berdasarkan analisis data, yang telah dilakukan maka dapat disimpulkan bahwa Bagaiamana Peningkatan Kompetensi Guru Dalam Menyusun Administrasi Pembelajaran Melalui Supervisi Akademik di SDN Jati Baru Tahun Pelajaran 2018/2019. Jumlah peningkatan dari $72,33 \%$ menjadi $100 \%$, dengan selisih peningkatan $27,7 \%$
\end{abstract}

\section{Keywords: Kompetensi Guru, Administrasi Pembelajaran, Supervisi Akademik}

\section{PENDAHULUAN}

Pendidikan adalah salah satu upaya yang dilakukan untuk memperbaiki sumber daya manusia. Salah satu upaya yang dilakukan untuk memperbaiki sumberdaya manusia adalah dengan memperbaiki proses pembelajaran di sekolah. Dalam meningkatkan kualitas sumberdaya manusia, guru mempunyai peran yang sangat penting. Keberhasilan siswa dalam belajar sangat dipengaruhi oleh bagaimana cara guru mengajar (Astuti, 2016).

Permendiknas No. 16 Tahun 2007 menyebutkan kompetensi guru SD/MI antara lain: 1) memahami prinsip-prinsip penilaian dan evaluasi proses dan hasil belajar sesuai dengan karakteristik lima mata pelajaran SD/MI; 2) menentukan aspek-aspek proses dan hasil belajar yang penting untuk dinilai dan dievaluasi sesuai dengan karakteristik lima mata pelajaran SD/MI; 3) menentukan prosedur penilaian dan evaluasi proses dan hasil belajar; 4) mengembangkan instrumen penilaian dan evaluasi proses dan hasil belajar; 5) mengadministrasikan penilaian proses dan hasil belajar secara berkesinambungan dengan mengunakan berbagai instrumen; 6) menganalisis hasil penilaian proses dan hasil belajar untuk berbagai tujuan; 7) melakukan evaluasi proses dan hasil belajar.

Namun kenyataan dilapangan masih jauh dari harapan atau belum sepenuhnya komponen itu dilaksanakan. Hasil observasi awal menunjukkan bahwa guru masih belum kompeten dalam menyusun administrasi pembelajaran dengan baik. Berdasarkan kondisi seperti telah dipaparkan diatas, maka kepala sekolah berupaya melakukan perbaikan dalam rangka peningkatan kompetensi pedagogik menggunakan supervisi akademik.

Menurut Arikunto (2006) kegiatan supervisi ada dua jenis yaitu supervisi akademik dan supervisi administrasi.Dari dua kegiatan supervisi yang ada, supervisi akademik merupakan kegiatan yang sangat potensial untuk meningkatkan kompetensi pedagogik guru .Potensi supervisi akademik tersebut oleh karena lingkupnya 
langsung pada kegiatan pembelajaran. Sedangan yang menjadi fokus dalam supervisi akademik adalah mengkaji, menilai, memperbaiki, meningkatkan, dan mengembangkan mutu kegiatan belajar mengajar yang dilakukan guru melalui pendekatan bimbingan dan konsultasi dalam nuansa dialog profesional.

Supervisi akademik merupakan serangkaian kegiatan membantu guru mengembangkan kemampuannya mengelola proses pembelajaran demi pencapaian tujuan pembelajaran Glickman (1981). Sementara itu, Daresh (1989) menyebutkan bahwa supervisi akademik merupakan upaya membantu guru-guru mengembangkan kemampuannya mencapai tujuan pembelajaran. Dengan demikian, esensi supervisi akademik itu sama sekali bukan menilai unjuk kerja guru dalam mengelola proses pembelajaran, melainkan membantu guru mengembangkan kemampuan profesionalismenya

Atas dasar pemikiran inilah yang menggugah perhatian penulis untuk melakukan penelitian dalam menyusun penelitian tindakan sekolah dengan mengangkat judul: Peningkatan Kompetensi Guru Dalam Menyusun Administrasi Pembelajaran Melalui Supervisi Akademik di SDN Jati Baru Tahun Pelajaran 2020/2021.

\section{METODE}

\section{Jenis Penelitian}

1. Penelitian ini adalah Penelitian Tindakan Sekolah (PTS). Kegiatan penelitian tindakan sekolah ini, dilaksanakan dalam 2 silus, tiap siklus terdiri dari empat tahapan, yaitu: perencanaan, pelaksanaan, pengamatan, dan refleksi (Nurfathurrmah, 2018)

\section{Waktu dan Tempat Penelitian}

Penelitian ini dilaksanakan di Jati baru, pada Semester Ganjil Tahun Pelajaran 2018/2019.

\section{Subyek Penelitian}

Subyek dalam penelitian ini adalah guru-guru di SDN Jati Baru sebanyak 12 orang.

\section{Rencana Tindakan}

Penelitian ini dilakukan dengan metode penelitian tindakan kelas yang berlangsung selama 2 siklus. Masing-masing siklus terdiri dari tahapan perencanaan, pelaksanaan, observasi dan refleksi. Metode penelitian yang dilakukan peneliti adalah dengan melaksanakan supervise akademik.Tahapan kegiatan dapat diuaraikan sebagai berikut:

\section{Perencanaan}

Pada tahap ini, peneliti merencanakan langkah-langkah sebagi berikut:

a. Mengidentifikasi jumlah guru yang sudah membuat silabus dan RPP

b. Meminta guru untuk mengumpulkan perangkat pembelajaran

c. Peneliti memeriksa administrasi guru secara kuantitas dan kulitatif.

d. Peneliti mengidentifikasi permasalahan yang ditemukan.

e. Menyusun rencana tindakan (berupa penjadwalan supervise individual atau kelompok disesuaikan dengan temuan pada identifikasi masalah)

\section{Pelaksanaan}

Pada tahap ini peneliti melaksanakan rencana tindakan supervise individual/kelompok untuk menilai administrasi guru yang sudah dikumpulkan sebelumnya. Pelaksanaan supervise dilakukan dengan pertemuan individual officeconference. Hal ini dilakukan terutama kepada guru yang tidak mengumpulkan perangkat pembelajaran, untuk mengetahui penyebab/masalahnya. Tahap ini peneliti rencanakan berlangsung selama 2 minggu dan dilaksanakan bersama-sama dengan kolaborator.

\section{Observasi}

Pada tahap ini peneliti melakukan kegiatan observasi terhadap seluruh kejadian yang terjadi selama tahap pelaksanaan dan mengobservasi hasil awal yang dicapai pada pelaksanaan tindakan siklus 1. Selain itu peneliti juga mengidentifikasi masalahmasalah lanjutan yang timbul dari pelaksanaan tindakan di siklus 1 .

\section{Refleksi}

Pada tahap refleksi, peneliti melakukan evaluasi terhadap tindakan dan data-data yang diperoleh. Kemudian dilanjutkan dengan 
pertemuan bersama kolaborator untuk membahas hasil evaluasi dan penyusunan langkah-langkah untuk siklus kedua.

\section{Instrumen Penelitian}

Instrumen yang digunakan dalam penelitian ini terdiri dari Lembar Observasi dan Lembar Evaluasi kegiatan.

\section{Teknik Analisis Data}

Analisis data menggunakan analisis deskriptif dan disajikan dalam persentase, yakni membandingkan persentase jumlah guru yang membuat administrasi mengajar dan perencanaan pembelajaran, dengan indicator Peningkatan pembuatan administrasi mengajar yang dilakukan oleh guru minimal $75 \%$.

\section{HASIL DAN PEMBAHASAN \\ Hasil Penelitian \\ Siklus I}

\section{Perencanaan}

Siklus pertama terdiri dari empat tahap yakni: (1) perencanaan, pelaksanaan, (3) pengamatan, dan (4) refleksi seperti berikut ini.

\section{a) Perencanaan}

Pada tahap perencanaan dilakukan kegiatan mempersiapkan:

1. Membuat lembar wawancara pra observasi dan pasca observasi

2. Membuat format/instrumen penilaian administrasi mengajar

3. Membuat format rekapitulasi hasil penyusunan silabus dan RPP siklus 1 dan siklus 2

4. Membuat angket guru tentang supervisi akademik dalam pelaksanaan pembelajaran

b) Pelaksanaan Tindakan

Pada awal siklus pertama administrasi mengajar yang dibuat para guru belum sesuai seperti keinginan peneliti. Hal itu dibuktikan dengan masih adanya komponen administrasi mengajar seperti 1) silabus, 2) RPP, 3) Prota, 4) Promes, 5) Daftar hadir (DH), dan 6) Daftar Nilai (DN) belum dibuat oleh guru. Kondisi awal guru SDN
Jati Baru yang membuat administrasi mengajar. Lebih jelasnya, prosentase jumlah guru yang mengumpulkan administrasi pembelajaran sebelum kegiatan adalah:

Tabel 1. Jumlah Guru yang membuat Administrasi Pembelajaran Siklus I

\begin{tabular}{|c|c|c|c|c|}
\hline No & Komponen & $\begin{array}{c}\text { Jumlah } \\
\text { seharusnya }\end{array}$ & $\begin{array}{c}\text { Yang } \\
\text { mengumpulkan }\end{array}$ & $\begin{array}{c}\% \text { yang } \\
\text { mengumpulkan }\end{array}$ \\
\hline 1 & Silabus & 12 & 12 & 100 \\
\hline 2 & RPP & 12 & 5 & 42 \\
\hline 3 & Program Tahunan & 12 & 7 & 58 \\
\hline 4 & Program semester & 12 & 8 & 67 \\
\hline 5 & Daftar Hadir & 12 & 8 & 67 \\
\hline 6 & Daftar Nilai & 12 & 12 & 100 \\
\hline & Jumlah & 72 & 52 & 434 \\
\hline \multicolumn{4}{|c|}{ Porsentasi yang mengumpulkan } & $72,33 \%$ \\
\hline
\end{tabular}

c) Pengamatan dan evaluasi

Dari tabel di atas jelas terlihat bahwa data dasar guru yang meyusun administasi pembelajaran berupa RPP sebanyak 12 orang atau $100 \%$, RPP 5 orang $42 \%$, Program Tahunan, 7 orang atau 58\%, Program semester 8 orang atau $67 \%$, Daftar hadi 8 orang atau $67 \%$, dan Daftar hadir 12 orang atau $100 \%$. Dengan total keseluruhan sebesar 52 atau $72,33 \%$. Dari hasil ini belum mencapai standar kriteria yang telah ditentukan yaitu $75 \%$, maka dilanjutkan pada siklus ke II, Selanjutnya mereka dibimbing atau dilakukan supervise dan disarankan untuk melengkapinya dengan pendekatan dialog kolaboratif.

d) Refleksi

Kegiatan refleksi berupa renungan atau pertanyaan yang dapat dijadikan acuan untuk melangkah ke siklus 2, diantaranya :

1. Guru kurang melengkapi semua administrasinya dengan lengkap

2. Belum ada sosialisasi tentang perubahan atau pengembangan administrasi mengajar

\section{Siklus II}

Melihat hasil siklus I yang kurang maksimal, maka guna memaksimalkan hasil yang diingin dicapai maka dilakukan siklus lanjutan. Siklus lanjutan ini juga terdiri dari tindakan perencanaan, pelaksanaan tindakan, observasi dan refleksi.

a) Perencanaan 
Pada tahap perencanaan dilakukan kegiatan mempersiapkan:
a. Membuat lembar wawancara pra observasi dan pasca observasi
b. Membuat format/instrumen penilaian administrasi mengajar
c. Membuat format rekapitulasi hasil penyusunan RPP penerapan model-model pembelajaran siklus 1 dan 2

d. Membuat angket guru tentang supervisi akademik dalam pelaksanaan pembelajaran

b) Pelaksanaan

Pada siklus ke-II administrasi mengajar yang dibuat para guru sudah sesuai seperti keinginan peneliti. Hal itu dibuktikan dengan masih adanya komponen administrasi mengajar seperti 1) silabus, 2) RPP, 3) Prota, 4) Promes, 5) Daftar hadir (DH), dan 6) Daftar Nilai (DN) belum dibuat oleh guru.

c) Pengamatan dan Evaluasi

Pengamatan dilaksanakan terhadap 12 orang guru. Semuanya menyusun administrasi mengajar, tapi masih ada guru yang belum sepenuhnya melengkapi komponen-komponen administrasi mengajar yang diperlukan, diantaranya. Lebih jelasnya, prosentase jumlah guru yang mengumpulkan administrasi pembelajaran sebelum kegiatan adalah:

Tabel 2. Jumlah Guru yang membuat Administrasi Pembelajaran Siklus II

\begin{tabular}{|l|l|c|c|c|}
\hline No & Komponen & $\begin{array}{r}\text { Jumlah } \\
\text { seharusnya }\end{array}$ & $\begin{array}{c}\text { Yang } \\
\text { mengumpulkan }\end{array}$ & $\begin{array}{c}\% \text { yang } \\
\text { mengumpulkan }\end{array}$ \\
\hline 1 & Silabus & 12 & 12 & 100 \\
\hline 2 & RPP & 12 & 12 & 100 \\
\hline 3 & Program Tahunan & 12 & 12 & 100 \\
\hline 4 & Program semester & 12 & 12 & 100 \\
\hline 5 & Daftar Hadir & 12 & 12 & 100 \\
\hline 6 & Daftar Nilai & 12 & 12 & 100 \\
\hline \multicolumn{2}{|c|}{ Jumlah } & 72 & 72 & 600 \\
\hline \multicolumn{2}{|c|}{ Porsentasi yang mengumpulkan } \\
\hline
\end{tabular}

Dari tabel di atas jelas terlihat bahwa data dasar guru yang meyusun administasi pembelajaran berupa RPP sebanyak 12 orang atau $100 \%$, RPP 12 orang $100 \%$, Program Tahunan, 12 orang atau $100 \%$, Program semester 12 orang atau 12\%, Daftar hadir 12 orang atau $100 \%$, dan Daftar hadir 12 orang atau $100 \%$. Dengan total keseluruhan sebesar 72 atau 100\%. Dari hasil ini sudah mencapai standar kriteria yang telah ditentukan yaitu minimal $75 \%$.

d) Refleksi

Berdasarkan hasil pengamatan pada siklus II baik guru maupun siswa sudah mengalami peningkatan dalam proses pembelajaran. Adapun hasil refleksinya sebagai berikut:

1. Guru sudah mampu melengkapi administrasi mengajar

2. Sudah ada sosialisasi pengembangan administrasi mengajar

3. Guru antusias dalam melengkapi administrasi mengajar

\section{PEMBAHASAN}

Hasil tindakan supervisi memberikan gambaran pada kondisi awal siklus I menunjukkan temuan skor kemampuan guru dalam penyusunan administrasi pembelajaran kondisi awal $72,33 \%$ pada setelah dilakukan tindakan supervisi terjadi peningktan pada siklus kedua menjadi $100 \%$. Hasil ini terlihat pada grafik berikut:

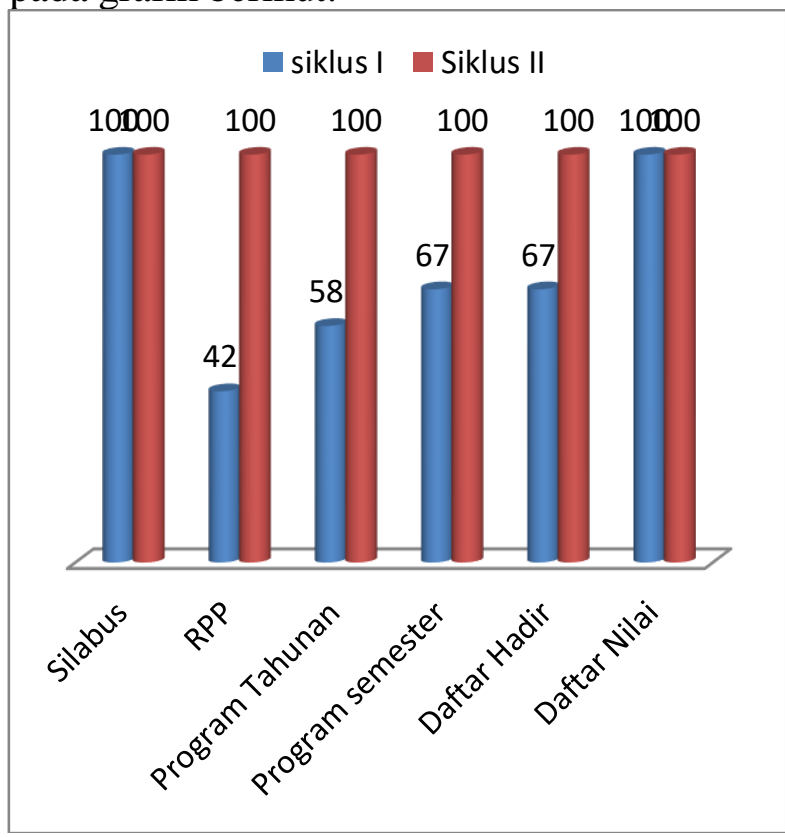

Gambar 1. Porsentase Guru yang Mengumpulkan Admistrasi Pembelajaran

Temuan ini mengindikasikan adanya peningkatan tingkat kemampuan guru dalam penyusunan administrasi pembelajaran. Besaran peningkatan sebesar $27,7 \%$, temuan tersebut telah mencapai keberhasilan. Temuan ini sejalan dengan penelitian Parwati Santi 
dkk (2013), Dalawi dkk (2012), dan Banun Sri Haksasi (2013)

Semua guru menunjukkan sikap yang baik dan termotivasi dalam menyusun administrasi mengajar dengan lengkap. Hal ini peneliti ketahui dari hasil pengamatan pada saat melakukan wawancara dan bimbingan penyusunan administrasi mengajar. Selanjutnya dilihat dari kompetensi guru dalam menyusun administrasi mengajar, terjadi peningkatan dari siklus 1 ke siklus 2 . Adanya keseriusan para guru yang disupervisi akademik menghasilkan tidak hanya peningkatan kemampuan mengajar mereka, melainkan juga administrasi mengajar mereka lengkap sehingga dapat meningkatkan mutu pembelajaran.

Pada siklus pertama semua guru mencantumkan identitas mata pelajaran dalam RPP penerapan model-model pembelajarannya (melengkapi RPP penerapan model-model pembelajarannya dengan identitas mata pelajaran). Pada siklus II guru tersebut mencantumkan identitas mata pelajaran dalam RPP dan melengkapi administrasi mengajar lainnya

\section{KESIMPULAN}

Berdasarkan hasil Penelitian yang telah dilakukan maka dapat disimpulkan bahwa Bagaiamana Peningkatan Kompetensi Guru Dalam Menyusun Administrasi Pembelajaran Melalui Supervisi Akademik di SDN Jati Baru Tahun Pelajaran 2018/2019. Jumlah peningkatan dari $72,33 \%$ menjadi $100 \%$, dengan selisih peningkatan $27,7 \%$.

\section{DAFTAR PUSTAKA}

Arikunto, Suharsimi. 2006. Dasar - Dasar Supervisi. Jakarta: Rineka Cipta.

Arikunto. S. 2010. Prosedur Penilitian Suatu Pendekatan Praktek. Jakarta:Renika Cipta.

Astuti, S. (2016). Penerapan supervisi akademik untuk meningkatkan kompetensi guru dalam menyusun administrasi penilaian di sd laboratorium uksw. Scholaria: Jurnal Pendidikan dan Kebudayaan, 6(1), 117-126.

Banun Sri Haksasi. 2013.Pelaksanaan
Supervisi Akademik Pada SMA Negeri 3 Semarang.Majalah Ilmiah Pawiyatan, $(x x): 4$

GavamediaSahertian, P.A .2010. Konsep

Dasar dan Teknik Supervisi

Pendidikan dalam Rangka

Pengembangan Sumber Daya

Manusia. Jakarta:

Rineka Cipta.

Nurfathurrahmah, N. (2018). Penerapan Model Problem Based Learning (PBL) Berbasis Kontekstual Terhadap Peningkatan Kemampuan Berpikir Kritis Mahasiswa. ORYZA Jurnal Pendidikan Biologi, 7(1), 2128.

Peraturan Mentri Pedidikan Nasional No. 16 Tahun 2007. 